\title{
Site information and initial results from deep ice drilling on Law Dome, Antarctica
}

\author{
V. I. Morgan, C.W. Wookey, J. Li, T. D. van Ommen, W. Skinner, M. F. Fitzpatrick \\ Antarctic Cooperative Research Centre and Australian Antarctic Division, GPO Box 252C, Hobart 7001, Australia
}

\begin{abstract}
The aim of deep ice drilling on Law Dome, Antarctica, has been to exploit the special characteristics of Law Dome summit, i.e. low temperature and high accumulation near an ice divide, to obtain a high-resolution ice core for climatic/ environmental studies of the Holocene and the Last Glacial Maximum (LGM). Drilling was completed in February 1993, when basal ice containing small fragments of rock was reached at a depth of $1196 \mathrm{~m}$. Accurate ice dating, obtained by counting annual layers revealed by fine-detail $\delta^{18} \mathrm{O}$, peroxide and electrical-conductivity measurements, is continuous down to $399 \mathrm{~m}$, corresponding to a date of AD 1304. Sulphate concentration measurements, made around depths where conductivity tracing indicates volcanic fallout, allow confirmation of the dating (for Agung in 1963 and Tambora in 1815) or estimates of the eruption date from the ice dating (for the Kuwae, Vanuatu, eruption 1457). The lower part of the core is dated by extrapolating the layer-counting using a simple model of the ice flow. At the LGM, ice-fabric measurements show a large decrease $\left(250\right.$ to $\left.14 \mathrm{~mm}^{2}\right)$ in crystal size and a narrow maximum in $c$-axis verticality. The main zone of strong singlepole fabrics however, is located higher up in a broad zone around $900 \mathrm{~m}$. Oxygen-isotope $\left(\delta^{18} \mathrm{O}\right)$ measurements show Holocene ice down to $1113 \mathrm{~m}$, the LGM at $1133 \mathrm{~m}$ and warm $\delta^{18} \mathrm{O}$ about the same as Holocene) ice near the base of the ice sheet. The LGM/Holocene $\delta^{18} \mathrm{O}$ shift of $7.0 \%$, only $\sim 1 \%$ larger than for Vostok, indicates that Law Dome remained an independent ice cap and was not overridden by the inland ice sheet in the Glacial.
\end{abstract}

\section{INTRODUCTION}

Law Dome is a small (200 km diameter) ice cap situated at the edge of the main East Antarctic ice sheet but with independent ice flow (Pfitzner, 1980). The Dome projects into the predominantly easterly atmospheric circulation produced by low-pressure systems centred around $65^{\circ} \mathrm{S}$ (Bromwich, 1988), and the disturbance it produces in the flow results in exceptionally high accumulation: up to $1.2 \mathrm{~m}$ ice equivalent on the eastern side of the Dome. The Dome Summit South (DSS) drilling site is $4.6 \mathrm{~km}$ south-southwest of the highest point on the dome $(\mathrm{A} 001)$. A location map is shown in Figure 1 and a "wire mesh" view of the bedrock topography in Figure 2.

The aim of the drilling has been to produce an accurately dated ice-core environmental record, with good time resolution in the Holocene, and extending back through the Last Glacial Maximum (LGM). The site facilitates this because the high annual accumulation results in unambiguous annual ice layers which can be reliably detected by a variety of measurements and counted to produce accurate dating.

Fieldwork started in 1987-88 with thermal drilling to $96 \mathrm{~m}$. The $270 \mathrm{~mm}$ diameter borehole made by the largediameter thermal drill was cased to a depth of $82 \mathrm{~m}$. In the following season an $18 \mathrm{~m} \times 7 \mathrm{~m} \times 5 \mathrm{~m}$ high corrugatedsteel arch shelter was set up over the casing, and the drill winch and support equipment installed. The electromechanical drill was completed and tested over the next 2 years. Electromechanical drilling to a depth of $553 \mathrm{~m}$ was carried out in 1991 -92, and the remainder of the drilling was completed in 1992-93. Silty ice containing small rock fragments was reached at a depth of $1196 \mathrm{~m}$, and drilling ceased when the drill cutters were damaged on a larger, basal rock fragment which grooved the core but was not recovered. The depth of the ice has been measured by radio-echo sounding (RES) at $1220 \mathrm{~m}$; however, due to the transmit pulse not being properly recorded, the uncertainty in the depth is estimated at $20 \mathrm{~m}$. The amount of silty basal ice is therefore not known but is probably less than $20 \mathrm{~m}$.

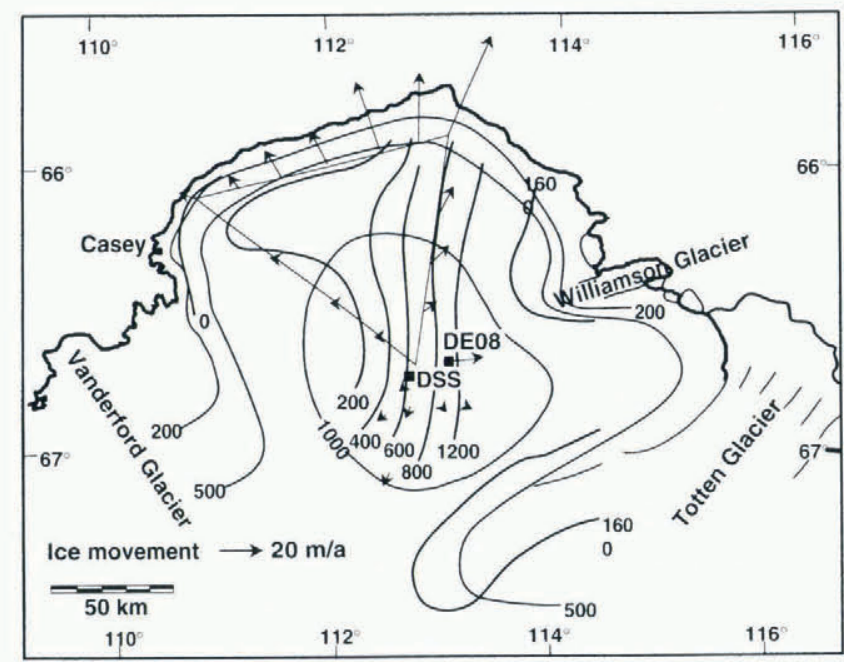

Fig. 1. Location map of DSS on Law Dome showing glaciological data. Elevation contours are light lines. Accumulation contours in $\mathrm{kg} \mathrm{m}^{-2}$ are the heavier lines. Measured ice-sheet surface velocities are indicated by arrowes of scale length. The highest point on the dome is the apex of the survey triangle nearest DSS. (Adapted from Xie and others (1989).) 


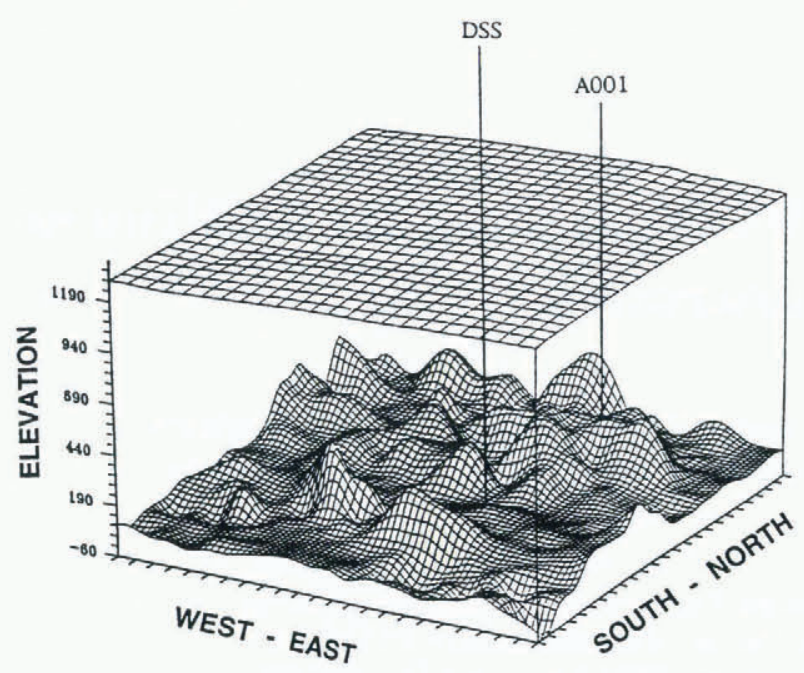

Fig. 2. "Wire mesh" view of the bedrock and ice surface around Law Dome summit. The survey grid is $15 \mathrm{~km} \times 15 \mathrm{~km}$, and the bedrock is exaggerated in the vertical by five times. The surface ice velocity is zero near (just north of) the highest point on the dome, A001.

On-site measurements were made of electrical conductivity, peroxide concentration, crystal size and orientation, and samples were cut for oxygen isotope ratio $\left(\delta^{18} \mathrm{O}\right)$, deuterium excess $\left(\delta=\delta D-\delta^{18} \mathrm{O}\right)$ and ${ }^{10} \mathrm{Be}$ determination. Continuous measurements stopped at $391 \mathrm{~m}$ because of time constraints and the difficulty of handling brittle core. Crystal size and orientation fabrics were measured over the full depth of the core. Ice from 552-1190 m was extremely brittle and was left in the drilling shelter to strain relieve over the 1993 winter. The bottom $6 \mathrm{~m}$ of ice had no visible bubbles and was not brittle.

\section{DRILLING SITE}

The high accumulation and moderate ice thickness near Law Dome summit result in an extended Holocene record, the Wisconsin/Holocene transition being quite close to the bedrock. Previous work on Law Dome (Morgan and McCray, 1985) and recent analysis of Greenland cores (Taylor and others, 1993) suggest that flow distortions and zones of enhanced shear in the lower layers of ice sheets can produce disturbances in ice-core data records. The DSS site was selected using RES to identify areas where laminar within-ice echoes extended to the greatest depth. These echoes (which are produced by small changes in the permittivity of the ice, e.g. from differing impurity levels) are generally thought to indicate past ice-sheet surfaces. On the basis that the laminar echoes indicate relatively undisturbed ice flow, the DSS site is removed from the summit (and ice divide) because RES there shows bedrock hills up to $250 \mathrm{~m}$ high, and within-ice layer echoes indicate disturbed ice flow at up to one-third of the ice thickness from the bedrock (Hamley and others, 1986). DSS is $4.6 \mathrm{~km}$ southsouthwest (bearing 195 ${ }^{\circ}$ ) from the summit in an area of relatively level bedrock (see Fig. 3).

The dynamics of the Law Dome ice sheet reflect the east-west accumulation gradient across the dome. On the western side, accumulation varies from 0 to $0.7 \mathrm{~m} \mathrm{a}^{-1}$ (ice equivalent), and ice surface velocities are generally less

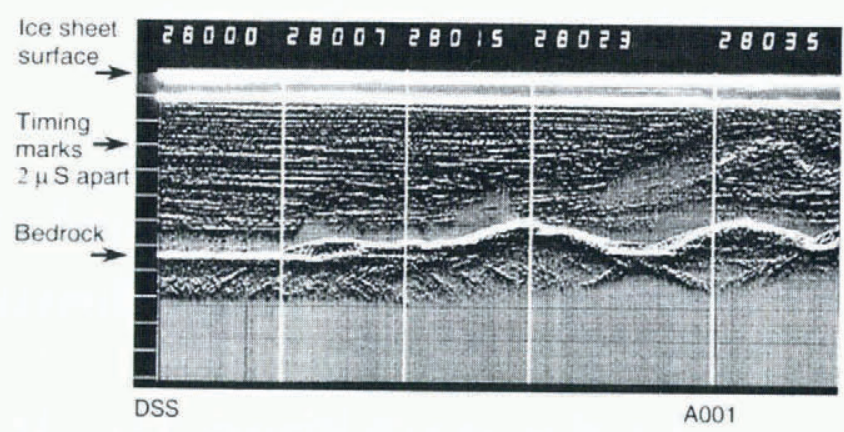

Fig. 3. RES profile along the flowline from the DSS borehole upstream to the dome summit, A001.

than $10 \mathrm{~m} \mathrm{a}^{-1}$. To the east, however, accumulation reaches $1.4 \mathrm{~m} \mathrm{a}^{-1}$, and at DE08, just $16 \mathrm{~km}$ downslope from the summit, accumulation is $1.2 \mathrm{~m} \mathrm{a}^{-1}$, and the ice flow towards Williamson Glacier reaches $18 \mathrm{~m} \mathrm{a}^{-1}$. DSS is on the accumulation isopleth which crosses the summit, and has a surface velocity of $2.9 \mathrm{~m} \mathrm{a}^{-1}$ at $220^{\circ}$. The RES profile shown in Figure 3 runs from DSS upstream to the dome summit at A001.

The mean annual temperature at DSS is $-21.8^{\circ} \mathrm{C}$, low enough to generally preclude melt in summer. Visible stratigraphy of the core indicates many thin glaze layers; however, these are fairly uniformly distributed and are therefore thought to be due to the action of wind on persisting surfaces rather than to radiation in the summer. Site parameters are summarised in Table 1.

\section{ICE-CORE DATING}

The high accumulation and the absence of very strong winds at Law Dome summit (see data of Allison and others, 1993) result in the formation and preservation of exceptionally clear annual accumulation layers. The seasonal accumulation layers are detected by fine-detail (10-15 points per year) $\delta^{18} \mathrm{O}, \mathrm{H}_{2} \mathrm{O}_{2}$ (Sigg and Neftel 1988), tracechemicals and electrical-conductivity (Hammer, 1980) measurements. $\delta^{18} \mathrm{O}$ is the principal indicator, the other measurements being used if necessary to resolve ambiguities. This is effective because different mechanisms produce the seasonal cycle in the different parameters. Only the irregularities in snowfall and accumulation affect all parameters, but at DSS these are relatively small. The clearest indicator is the peroxide trace because its production is modulated by the regularly varying solar radiation; however, the nonautomated peroxide measurements are very time-consuming, so the record is not complete. Figure 4 shows a section

\section{Table 1. DSS site parameters}

\section{Latitude}

Longitude

Surface elevation

Distance from dome summit

Ice thickness (by RES)

Borehole depth

Mean annual temperaturc

Temp. at bottom of borehole

Last 50 years' mean accumulation

Surface ice movement

Mean wind speed $66^{\circ} 46^{\prime} 11^{\prime \prime} \mathrm{S}$

$112^{\circ} 48^{\prime} 25^{\prime \prime} \mathrm{E}$

$1370 \mathrm{~m}$

$4.68 \mathrm{~km}$ at 195

$1220 \pm 25 \mathrm{~m}$

$1195.6 \mathrm{~m}$ below the

1987-88 surface

$-21.8^{\circ} \mathrm{C}$

$-6.9^{\circ} \mathrm{C}$

$0.70 \mathrm{~m}$ (ice equivalent

$2.9 \mathrm{~m} \mathrm{a}^{-1}$ at $220^{\circ}$

$8.3 \mathrm{~m} \mathrm{~s}^{-1}$ 
of fine-detail measurements. Currently, layer-counting is continuous to $399 \mathrm{~m} \mathrm{(AD} \mathrm{1304),} \mathrm{and} \mathrm{spot} \mathrm{measurements} \mathrm{of}$ layer thickness (from fine-detail isotope and peroxide measurements) are used to constrain an ice-flow model which is used to extrapolate the dating further down. The deepest annual layers so far detected (by peroxide) are at $1080 \mathrm{~m}$ where the thickness is $18 \mathrm{~mm}$. Ultimately it is expected that accurate dating will be obtained by layer-counting and interpolation to a depth of about $1100 \mathrm{~m}$ ( 8000 BP).

In the 683 years of continuous isotope data there are about 15 places where the annual $\delta^{18} \mathrm{O}$ cycles are ambiguous. Cross-checking with peroxide and electrical-conductivity data resolves about half of these, leaving a dating uncertainty of $1 \%$. An absolute check on the dating is obtained by identifying fallout from well-dated volcanic eruptions. The eruption dates of Agung (1963), Krakatau (1883) and Tambora (1815) all agree with the dating from layercounting, although the exact position of the Krakatau peak is not clear, because the sulphate-poor eruption is almost masked by background sea-salt sulphate. A large sulphate peak found at a depth corresponding to the austral summer 1458-59 is assumed to be due to the eruption of Kuwae, Vanuatu. The size of this eruption, which Monzier and others (1994) suggest is one of the largest in the last

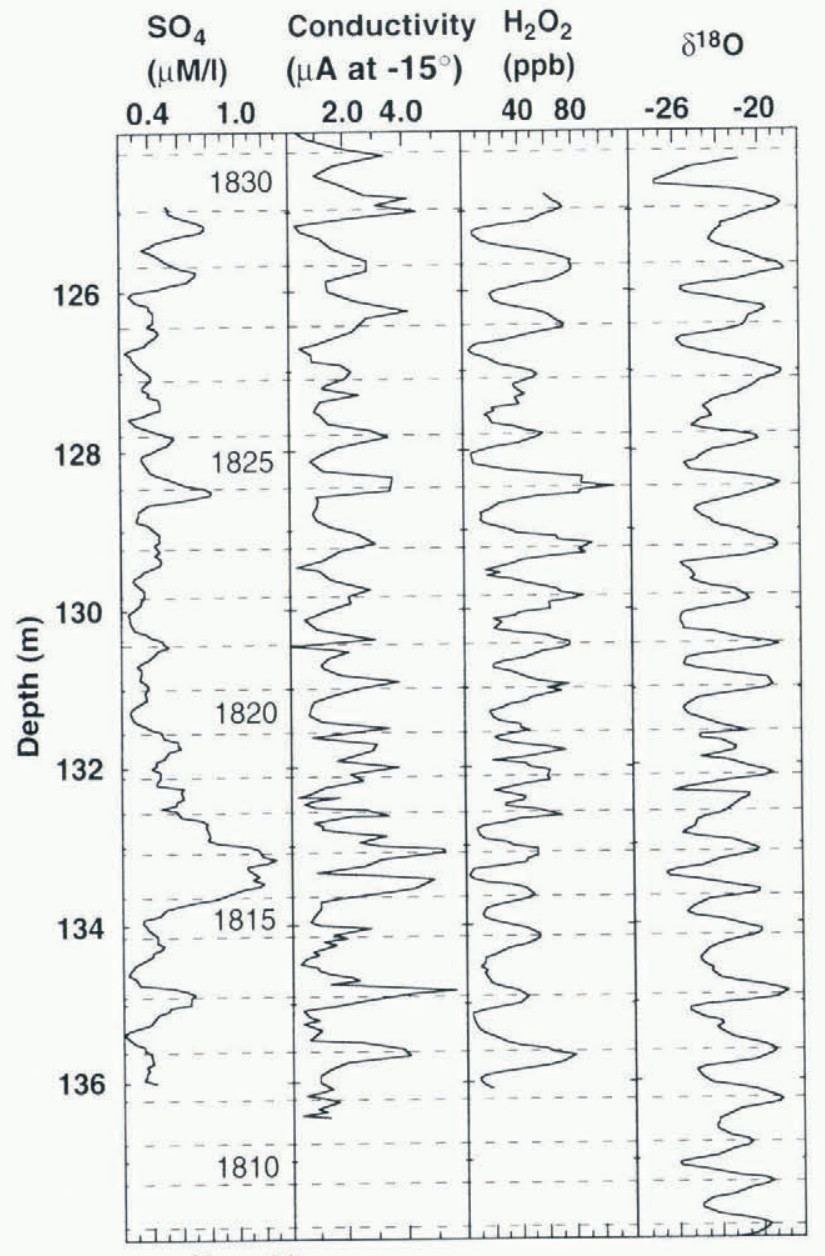

Year AD

Fig. 4. Fine-detail $\delta^{18} O$, peroxide, electrical conductivity and sulphate data. The Tambora (Indonesia) volcanic eruption of 1815 is seen as the small enhancement in the conductivity profile and the much larger increase in sulphate concentration around $133 \mathrm{~m}$ depth. The data around $132 \mathrm{~m}$ are one of the more ambiguous sections of the record.
10000 years, has only recently been recognised because the caldera is submerged. It is the largest peak in the DSS record, with nearly 1.5 times as much sulphate as the next largest, Gunung Tambora in 1815. Monzier and others used radiocarbon dating to place the eruption of Kuwae between 1420 and 1450; however, Pang (1993) has used historical data to obtain a precise date of 1453 . Data from several Antarctic and Greenland cores (Langway and others, 1995) put the date between 1450 and 1464, with the best-dated cores giving 1457 and 1459. Both the G15 (Mizuo) core (Moore and others, 1991) and the GISP2 core, Greenland (Zielinski and others, 1994), give the date of Kuwae as 1459-60, making Pang's earlier date difficult to accommodate. Current DSS layer-counting dates the onset of fallout to late 1458, which implies an eruption in 1457, since aerosols injected in mid- or low latitudes generally take 6-12 months to diffuse to the polar regions (Handler, 1989) and entry into the polar stratosphere usually occurs in spring after the breakdown of the polar vortex (Deshler and others, 1992). A generous interpretation of the accumulation layers is required to find an extra 4 years in the DSS record between the fixed point at 1815 and 1457. Confirmation of the date of this eruption by an alternative precision method (e.g. tree-ring counting) is required. Ice-core sulphate levels from volcanic fallout are shown in Figure 5.

Dating for the whole core has been calculated using the Dansgaard and Johnsen (1969) modification of the Nye
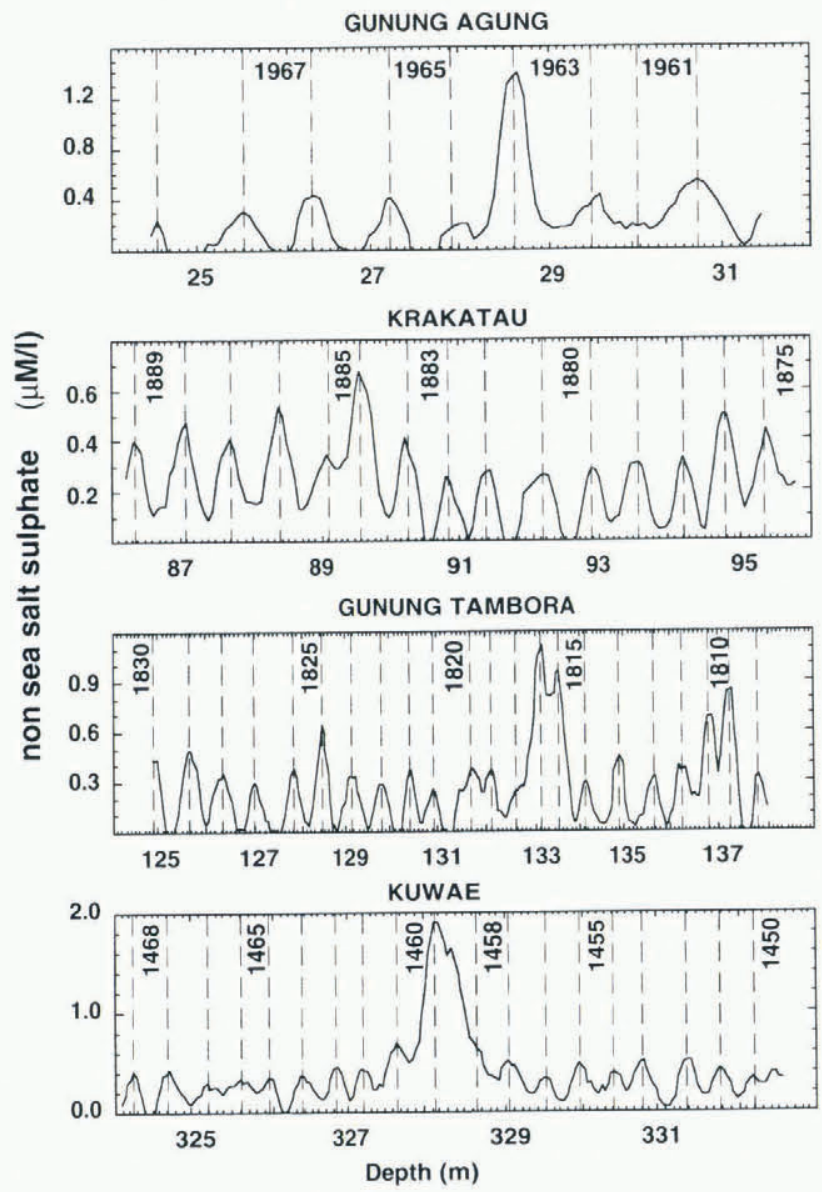

Fig. 5. Non-sea-salt sulphate concentrations at depths corresponding to the dates of known explosive volcanic eruptions or where conductivity measurements indicated high acidity levels. The sea-salt component is removed by subtracting 0.052 times the chloride concentration. 
time-scale to extrapolate the dating obtained by layercounting. This model assumes the vertical strain rate is uniform from the surface down to a specific depth (break point) and then decreases linearly to zero at the bed. The equations strictly apply only at an ice divide, or at a location where the ice thickness and accumulation are constant upstream to the ice divide. DSS is only four ice thicknesses from the summit, and the thickness and accumulation vary little in this distance, so the error introduced is small.

For the DSS core, as noted earlier, the total ice-sheet thickness is not precisely known at this stage. For this reason, the equations of Dansgaard and Johnsen (1969) have been recast in terms of ice depth rather than height above the base of the ice sheet. This gives equations which are independent of the ice-sheet thickness in the region above the break point in ice flow (i.e. the point at which the modelled vertical strain rate starts to decrease). Layer thickness and age relationships then simplify to:

1. From the surface down to the break point

Layer thickness, $\lambda(d)=\frac{D-d}{D} \lambda_{S}$

$$
\text { Layer age, } t(d)=\frac{D}{a} \ln \frac{D}{D-d}
$$

2. At the break point $\left(\right.$ depth, $d_{\text {break }}=2 D-T$ )

$$
\begin{aligned}
\lambda\left(d_{\text {break }}\right) & =\frac{T-D}{D} \lambda_{S} \\
t\left(d_{\text {break }}\right) & =\frac{D}{a} \ln \frac{D}{T-D}
\end{aligned}
$$

3. Below the break point

$$
\begin{aligned}
\lambda(d)= & \lambda\left(d_{\text {break }}\right) \\
& \cdot\left[1+\frac{\lambda\left(d_{\text {break }}\right)}{1 \text { year }} \frac{t(d)-t\left(d_{\text {break }}\right)}{2(T-D)}\right]^{-2} \\
t(d)= & \frac{2 D}{a} \frac{T-2 D+d}{T-d}+t\left(d_{\text {break }}\right)
\end{aligned}
$$

where $d$ is the ice-equivalent depth; $\lambda_{S}$ and $D$ are the intercepts of the above-break linear region with a thickness and depth axes, respectively; the parameter $a$ is the ice-equivalent annual accumulation $\lambda_{S} /(1$ year); and $T$ is the iceequivalent total ice thickness.

The layer-thickness data were fitted to this model using a non-linear least-squares algorithm for the parameters $a, D$ and $T$. The thickness data and the fit are plotted in Figure 6, and the values derived are:

$$
\begin{aligned}
a & =0.6781 \pm 0.0006 \mathrm{~m}_{\text {year }}{ }^{-1} \\
D & =1054.4 \pm 0.6 \mathrm{~m} \\
T & =1178 \pm 2 \mathrm{~m}
\end{aligned}
$$

The ice-equivalent quantities have been computed from an exponential firn-density model (Paterson, 1994, p. 14) based on measured densities. Dating of pre-Holocene ice is problematic. The effect of variations in the accumulation rate, icesheet size and flow properties of the basal ice is difficult to estimate. The approach used to estimate ages prior to the Holocene has been to apply the same model and parameters with an adjusted accumulation rate of $40 \%$ of the Holocene value. Using this method, the computed age at the LGM is 13 800 years. Based on the observed sensitivity of the model to errors in the measured layer thicknesses, and uncertainties in Wisconsin accumulation, the estimated uncertainty in this age is approximately $20 \%$. Modelled ages improve in accuracy at shallower depths, with estimated un-

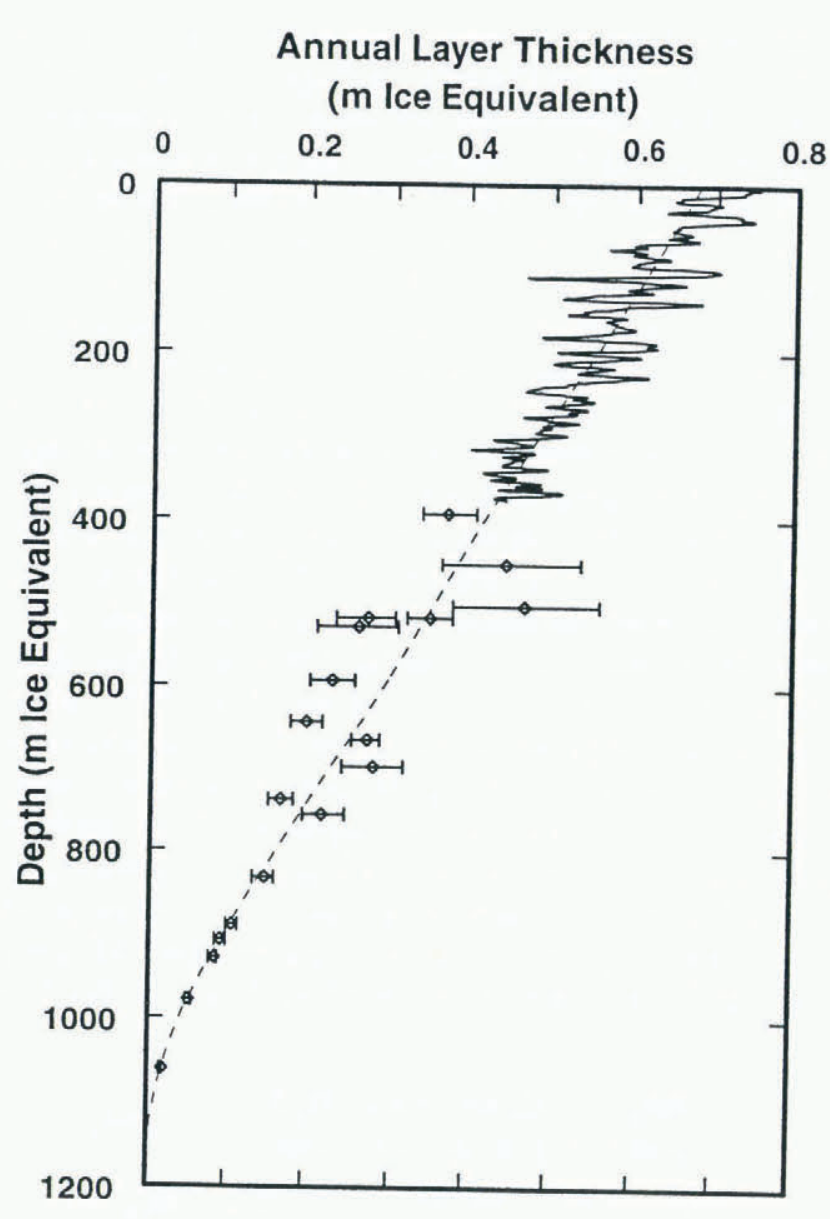

Fig. 6. DSS measured annual layer thickness (in ice equivalent) and the model data. The top $391 \mathrm{~m}$ of continuous data have been smoothed with a Gaussian filter of RMS width 3 years. The data points below $391 \mathrm{~m}$ are obtained from typically 6 years'data, and the indicated errors are of $1 \sigma$ amplitude. The broken line showes the best-fit model which is used for dating.

certainties of $\sim 10 \%$ at 7000 years and $\sim 5 \%$ at 4000 years. The dating obtained is shown with the isotope profile in Figure 7.

\section{ISOTOPE/CLIMATE RECORDS}

The complete DSS $\delta^{18} \mathrm{O}$ profile is shown in Figure 7. The data are smoothed in the depth domain by differing amounts at different depths to compensate for changes in the sampling interval and layer thickness.

The $7.0 \%$ shift in $\delta^{18} \mathrm{O}$ between the LGM and the Holocene is about the same as that for the coastal Law Dome cores BHC-1 and BHC-2 (Morgan and McCray, 1985); however, the transition is sharper in DSS because all the ice originates from the same site. In BHC-1 and BHC-2 the surface ice is deposited near the drilling sites at low elevations, while the deeper, older ice originated upstream from near the summit of the ice sheet. The $3.0 \%$ change in surface $\delta^{18} \mathrm{O}$ values between the edge and the summit of Law Dome therefore results in a curved Holocene $\delta^{18} \mathrm{O}$ profile for the coastal cores which blends smoothly into the transition to the LGM. This makes it difficult to determine accurately the size of the Holocene/LGM change because correcting the profiles for deposition site is hindered by the lack of an accurate time-scale for the coastal cores. The $7.0 \%$ Holocene/LGM $\delta^{18} \mathrm{O}$ shift at DSS is larger than that 


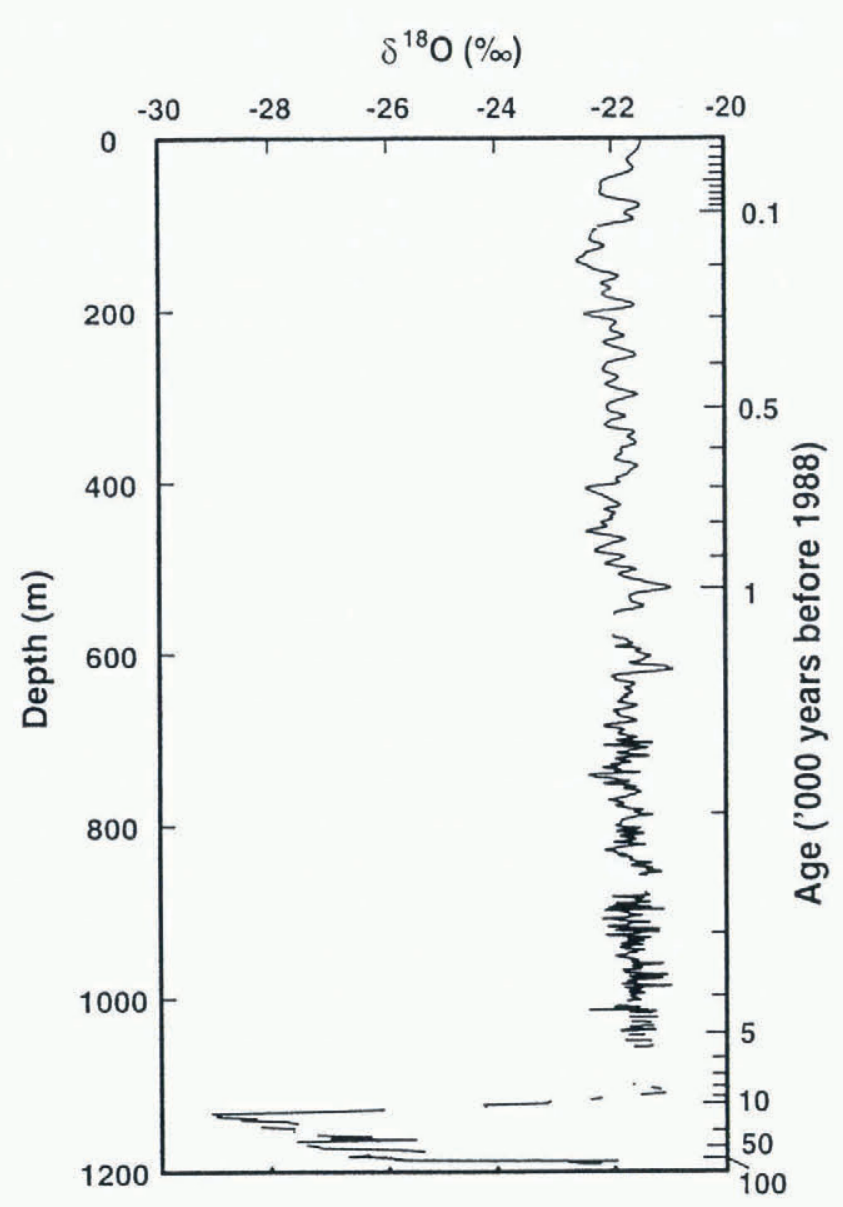

Fig. 7. Oxygen-isotope ratio profile for DSS ice core. The top $391 \mathrm{~m}$ is from smoothed fine-detail ( 10 per year) measurements. The $391-1000 \mathrm{~m}$ section comprises $0.5 \mathrm{~m}$ contiguous samples. The transition, LGM and Wisconsinan, is from spot samples, and the basal ice is sections with measurements at $10 \mathrm{~mm}$ intervals.

found for inland East Antarctica where Dome C gave 5.8\%o (Lorius and others, 1981), and Vostok 6.0\% (Jouzel and others, 1987). A larger isotopic shift for coastal cores was also observed in cores from Terre Adélie (Yao and others, 1990). Yao and others attributed the additional $\delta^{18} \mathrm{O}$ shift to additional temperature change resulting from ice-sheet lowering at the end of the LGM. The retreat of the ice sheet at the end of the LGM, in response to increasing sea level, does decrease surface elevation at the periphery more than near the centre; however, recent work suggests that changes were relatively small around much of the margin, and the expansion to the edge of the continental shelf was limited to the outlet glaciers. Domack and others (1991) support this with sediment core data from Terre Adélie, and Goodwin $(1993,1995)$ uses geomorphological evidence to estimate the expansion in the Law Dome area to about $15 \mathrm{~km}$. The DSS $\delta^{18} \mathrm{O}$ record also restricts the amount of ice-sheet expansion in the Law Dome area.

If, at the LGM, the Vanderford Glacier trough was icefilled and the main ice sheet extended out $60-100 \mathrm{~km}$ to the edge of the continental shelf as suggested by Cameron (1964), Law Dome would have been overridden by the main East Antarctic ice sheet (as indicated by Budd and Morgan, 1977). In this case, Last Glacial ice from DSS would have $\delta^{18} \mathrm{O}$ values reflecting its origin at an inland site of considerably higher elevation than the present Law
Dome summit. The shift to Holocene $\delta^{18} \mathrm{O}$ values would thus comprise a global temperature signal component and a component due to the source shift to lower elevations nearer the ocean. Ice inland of Law Dome at an elevation of $2000 \mathrm{~m}$ (the estimated source region for an overridden Law Dome) has a present-day $\delta^{18} \mathrm{O}$ value of $-30 \%$. This is $8 \%$ lower than present-day Law Dome summit values and, combined with a temperature-induced change of $6 \%$, leads to a Holocene/LGM change of $14 \%$, twice the observed value. There are a number of other factors which influence $\delta^{18} \mathrm{O}$ values and therefore contribute to the larger $\delta^{18} \mathrm{O}$ shift at coastal sites. These include expansion of the ice sheet or ice shelves in areas away from Law Dome, and increased sea-ice extent in the glacial, both of which increase watervapour fractionation by effectively increasing the distance from water-vapour sources; and changes in atmospheric circulation, especially the latitude of the circulating low-pressure systems which provide most of the precipitation on the coastal ice sheet.

The Holocene record (i.e. from just after the LGM/ Holocene transition to the last few hundred years), indicates a trend of decreasing $\delta^{18} \mathrm{O}$ values amounting to about $0.6 \%$. Since a similar trend is also observed in both Dome C and Vostok the simplest explanation is a small decrease in global (or at least Southern Hemisphere) temperature of the order of $1^{\circ} \mathrm{C}$ over the last 10000 years. The lowest $\delta^{18} \mathrm{O}$ values in the Holocene are actually around $150 \mathrm{~m}$ depth (deposition date $\sim \mathrm{AD} 1800$ ), corresponding to the period of colder temperatures and glacier advance in the Northern Hemisphere sometimes known as the Little Ice Age. The record also suggests a relatively rapid temperature rise in the last 100 years with present-day temperatures nearly the same as those of the early Holocene. Although the rapid recent rise probably indicates a real temperature increase, the longer decreasing trend could be due to changes in icesheet elevation. An elevation increase of $185 \mathrm{~m}$ on Law Dome is required for the $0.6 \%$ o $\delta^{18} \mathrm{O}$ change (from the present-day $\delta^{18} \mathrm{O} /$ elevation relation), and this would be quite possible, only requiring a $1.8 \mathrm{~cm}$ year ${ }^{-1}$ mass imbalance (in an accumulation of $69 \mathrm{~cm}$ ) for 10000 years. Recent work by Goodwin (1993, 1995), however, indicates an elevation increase of $30-50 \mathrm{~m}$ on Law Dome in response to the increased accumulation in the Holocene as compared with the glacial. An elevation change of the order of $185 \mathrm{~m}$ in the vicinity of Dome $\mathrm{C}$ or Vostok requires a large fractional change in accumulation and therefore seems much less likely.

At the bottom of DSS is $6 \mathrm{~m}$ of basal ice which has $\delta^{18} \mathrm{O}$ values slightly more negative than most of the Holocene and the present-day precipitation. These $\delta^{18} \mathrm{O}$ values indicate just slightly lower temperatures than today, and imply that the ice is from the last Interglacial, i.e. at least 110000 years old. A few microparticle measurements which show numbers similar to Holocene ice reinforce this interpretation. An alternative interpretation is that this is even more ancient ice, from the original build-up of the ice sheet. This interpretation follows from comparison with basal ice at the bottom of the Greenland ice sheet at GRIP which Souchez and others (1994) propose is $\sim 2400000$ years old. If the ice is this old, however, its flow rate must be essentially zero, which implies that all the surface velocity of the ice sheet comes from deformation above the basal ice. For DSS, future measurements of the borehole deformation aim to 
determine the internal strain and if accurate enough will put limits on the movement of the basal ice.

\section{GRYSTAL SIZE AND $C$-AXIS ORIENTATION FABRICS}

Crystal size and $c$-axis orientations were measured on-site following core recovery, in order to avoid possible changes in crystal structure due to stress release during core storage. Thin sections, typically $0.4-0.8 \mathrm{~mm}$ thick depending on crystal size, were taken between $117.3 \mathrm{~m}$ and the bottom core at $1195.6 \mathrm{~m}$ at about $5 \mathrm{~m}$ spacing. Mean crystal area was determined by counting crystals in a given area of a thin section when the sections were mounted between crossed polaroids. Crystal orientations were measured with a modified Rigsby stage (Morgan and others, 1984). In the fine-grained ice more than 100 crystals in a section were measured, but in some zones with large crystals a full core section would contain less than 100 crystals. Crystal size was measured in both horizontal and vertical thin sections, while $c$-axis orientations were measured only in horizontal thin sections. Figure 8 shows profiles against depth, of crystal mean area, mean half-girdle angle and selected fabric diagrams. The top $300 \mathrm{~m}$ is the normal-crystal growth zone where the growth rate is controlled mainly by temperature. For DSS, the mean area increases from $4.2 \mathrm{~mm}^{2}$ at $117.3 \mathrm{~m}$ to $15 \mathrm{~mm}^{2}$ at about $300 \mathrm{~m}$, and a regression fit of the data gives a crystal-growth rate of $0.0384 \mathrm{~mm}^{2}$ year $^{-1}$. This value cor- responds to a temperature of $-9.8^{\circ} \mathrm{C}$ using Paterson's (1994) relation, but DSS borehole-temperature measurements show that the temperature from near surface to $400 \mathrm{~m}$ is approximately constant at $-21^{\circ} \mathrm{C}$. The faster than expected growth rate for this temperature is attributed to the relatively high deformation rate at DSS which is a consequence of high accumulation. Although fabric patterns are generally close to random distribution in the upper $200 \mathrm{~m}$, a small amount of central tendency is apparent by $300 \mathrm{~m}$, indicating significant deformation by this depth $(\mathrm{Li}, 1996)$. At this stage of development, where crystals are much smaller than the equilibrium size for the stress situation (Jacka and Li, 1994), the higher strain rate facilitates the grain-boundary migration, which leads to larger crystals. An even larger effect has been observed in the DE08 core which comes from an even higher accumulation site on Law Dome.

Crystal growth between 300 and $1000 \mathrm{~m}$ is characterised by large fluctuations around a general increase in crystal size. Crystal fabrics continue to strengthen, with strong singlemaximum patterns forming between 620 and $1000 \mathrm{~m}$, suggesting that simple shear becomes dominant with increasing depth. The development of the single-maximum fabrics is erratic, however, with some relatively weak (less concentrated) patterns often found between strong singlemaximum fabrics. Detailed comparison between crystal size and fabric profiles shows that variations of crystal size are strongly related to crystal fabrics, with the larger crystal-size sections having weaker fabrics and the smaller ones having

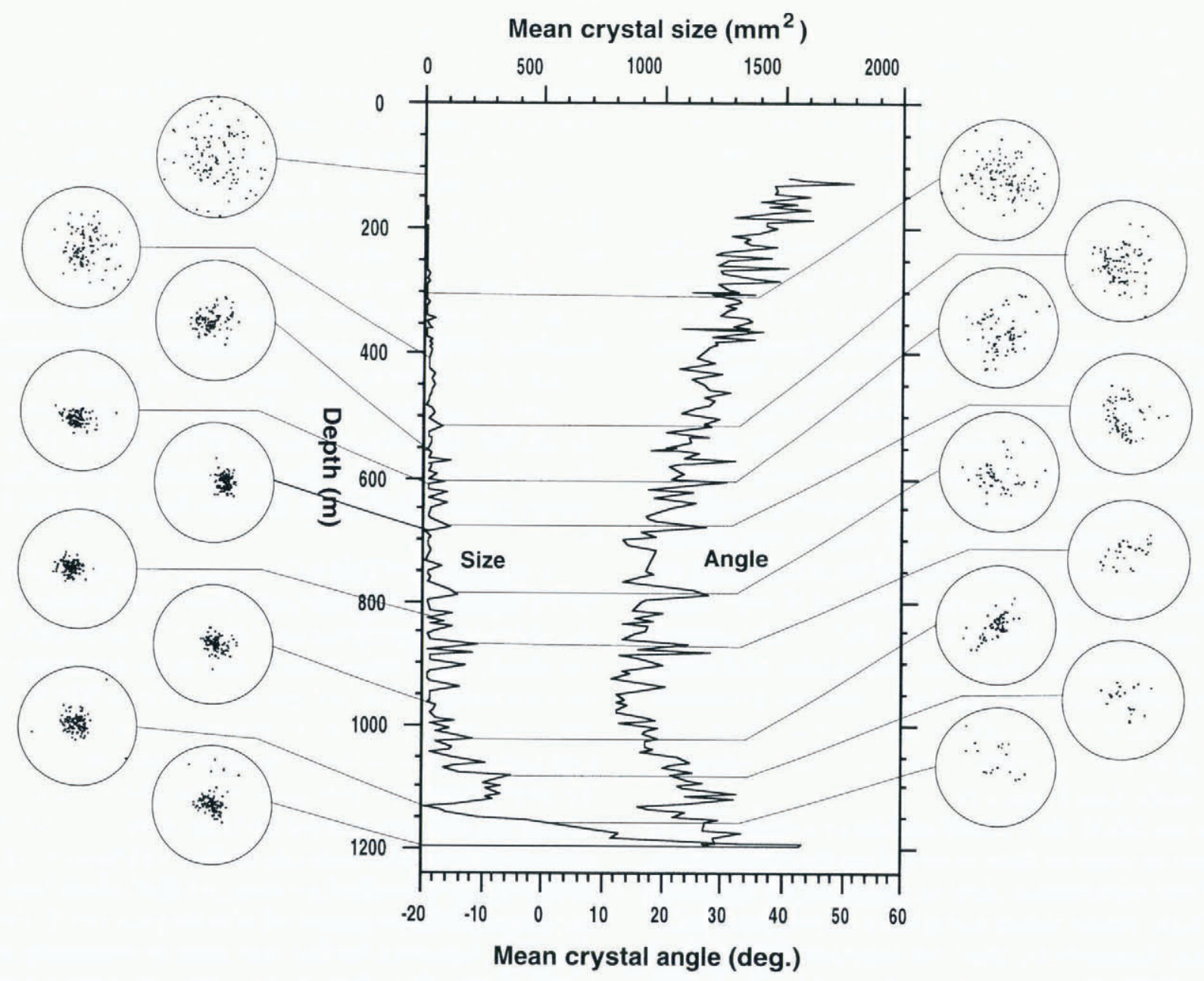

Fig. 8. Summary of ice-crystal structure. Average crystal size and mean crystal angle (c-axis co-latitude) vs depth. A selection of fabric diagrams is included. 
stronger fabrics as shown in Figure 8. The reason for this variation is not known at this stage, although the ice-flow feedback mechanism (in which more oriented sections have enhanced deformation which in turn enhances orientation and smaller crystals by polygonization) can maintain or magnify initial variations. Further investigations of the differences in physical properties (such as chemical and particulate concentrations) between the large and small crystal ice are planned.

Below about $1000 \mathrm{~m}$, crystal size rapidly increases with depth, from about $70 \mathrm{~mm}^{2}$ to greater than $1500 \mathrm{~mm}^{2}$ near the bottom of the core, in association with the development of multi-maximum fabric patterns. This ice appears to correspond to zones with low shear deformation rates and high temperatures (borehole temperatures increase from about $-14^{\circ}$ to $-7^{\circ} \mathrm{C}$ ). The highly compressed time-scale in the basal ice allows the large crystals to be developed by approximately the same growth rate as in the upper levels. At the bottom of the core $(1195.6 \mathrm{~m})$ the ice contains a large amount of fine visible impurity and exhibits very fine crystals (area $\sim 6.9 \mathrm{~mm}^{2}$ ) with a strong single-maximum fabric. A vertical thin section shows the sudden change from large crystals in clean ice to fine crystals in silty ice within a few millimetres. While the small crystals may be a result of inhibited growth, restrained by the large amount of impurities (Koerner and Fisher 1979), the strong single-maximum fabric implies that the ice is undergoing (or at least has undergone) considerable shear deformation. Tison and others (1994) suggest that Greenland ice which exhibits a similar fabric is locally formed ice which was overridden and entrained by the growing ice sheet. Shear deformation occurring in the growth phase produced the well-developed fabric which was then preserved in the nearly stagnant ice by the high particle content which limits recrystallization. Along with the general trend of crystal growth and decrease of fabric strength in the last $200 \mathrm{~m}$ of the core, a sharp reversal of the trend, over a few metres, is found around $1133 \mathrm{~m}$. At this depth, which corresponds exactly to the LGM as indicated by the oxygen-isotope data, crystal size drops abruptly from around $300 \mathrm{~mm}^{2}$ to $14 \mathrm{~mm}^{2}$ in association with development of very strong single-maximum fabric. Preliminary particle measurements Coulter-counter technique) have shown that the particle concentration at $1133 \mathrm{~m}$ is about 1-2 magnitudes higher than above or below the LGM. There is also some evidence from initial borehole logging of a shear band of high horizontal flow rate at this depth, but confirmation and magnitude determination must wait until the borehole is re-logged in the future. Fine crystals and strong single-maximum $c$-axis fabrics are commonly found in Wisconsin (and particularly LGM) ice, but the cause is still not clear. Paterson (1991) has concluded that some of the soluble impurities such as chloride and sulphate impede grain-boundary migration and grain growth so that the crystals remain small, and the small crystals facilitate the development of the single-maximum fabric by speeding up recrystallization. The positive feedback to ice deformation then further strengthens the fabric and keeps the crystals small. Paterson limits his conclusion to areas where the Wisconsin ice exists in the lower part of ice thickness and where the stress configuration produces simple shear deformation.

Gow and Williamson (1976) and Budd and Jacka (1989) have shown that simple shear deformation results in ice with single-maximum fabric and fine crystal size. Further work by Jacka and Li (1994) has shown that the steady-state crystal size inversely depends on the magnitude of the stress. In steady-state tertiary flow, higher stress results in smaller crystal size. In Law Dome, most of the strong singlemaximum fabric ice with small crystals has been found at a depth well above Wisconsin ice (Xie, 1985; Li and others, 1988). At DSS, the minimum crystal size found between 600 and $1000 \mathrm{~m}$ generally corresponds to a stronger singlemaximum fabric. The smaller crystal sizes have similar values to those found in Wisconsin ice where strong singlemaximum fabric occurs $(1133 \mathrm{~m})$. Recent laboratory ice-deformation tests using ice samples carefully selected from Holocene and Wisconsin ice from Greenland, Agassiz and Antarctic ice sheets have found that Wisconsin ice at the tertiary deformation stage has no special properties, either in ice flow or in crystal size and fabric (Wang, 1994). This implies that the strong single-maximum/fine crystal-size fabric found in polar ice sheets at the LGM is not solely due to high impurity levels but must also be driven by conditions in the ice sheet. It is observed that the LGM shear zone usually arises where this layer is situated at a depth where the shear stress is a maximum, stress in the ice at greater depth being reduced by the effect of bedrock relief (Budd and RowdenRich, 1985). To help answer the questions raised by the fabric and flow variations, annealing experiments using samples with similar crystal size and fabrics carefully selected from the DSS core at various depths in the Holocene, Wisconsin and pre-Wisconsin periods are being performed.

\section{CONCLUSION}

The DSS ice core contains $1113 \mathrm{~m}$ of Holocene ice $\left(\delta^{18} \mathrm{O} \sim\right.$ $-22 \%$, , $20 \mathrm{~m}$ of LGM/Holocene transition ice, $54 \mathrm{~m}$ of ice from the Last Glacial $\left(\delta^{18} \mathrm{O}=-26\right.$ to $-28 \%$, ) and about $9 \mathrm{~m}$ of basal ice with $\delta^{18} \mathrm{O} \sim-22 \%$. The $\delta^{18} \mathrm{O}$ value of the ice from the glacial confirms that Law Dome existed as an independent ice sheet at this time. The large thickness of Holocene ice, and the rapid thinning which results in the entire glacial being compressed into $54 \mathrm{~m}$, is a consequence of the very high accumulation rate at the site. Also resulting from the high accumulation are the clearly defined annual layers, which permit accurate dating $( \pm 1 \%)$ by simply counting layers down from the surface. Fallout from the eruptions of Agung and Tambora is used to confirm the dating, while the eruption date of Kuwae, Vanuatu, is put at 1457 by the ice-core dating. The linear thinning found in the top $1000 \mathrm{~m}$ implies uniform strain, and the measured strain rate is used in a simple model of the ice flow to extrapolate the dating towards the bedrock. Ice-crystal size generally increases down the core except at the LGM where there is a distinct minimum. Crystal fabric development correlates inversely with size both generally and in the small-scale variations.

\section{REFERENCES}

Allison, I., G. Wendler and U. Radok. 1993. Climatology of the East Antarctic ice sheet $\left(100^{\circ} \mathrm{E}\right.$ to $\left.140^{\circ} \mathrm{E}\right)$ derived from automatic weather stations. J. Geophys. Res., 98 (D5), 88158823.

Bromwich, D. H. 1988. Snowfall in high southern latitudes. Rev. Geophys., 26 (1), 149-168.

Budd, W. F. and T. H. Jacka. 1989. A review of ice rheology for ice shee modelling. Cold Reg. Sci. Technol., 16 (2), 107-144.

Budd, W. F. and V. I. Morgan. 1977. Isotopes, climate and ice sheet dynamics 
from core studies on Law Dome, Antarctica. International Association of Hydrological Sciences Publication 118 (Symposium at Grenoble 1975 - Isotopes and Impurities in Snow and Ice), 312321.

Budd, W. F. and R. J. M. Rowden-Rich. 1985. Finite element analysis of twodimensional longitudinal section flow on Law Dome. A.NARE Res. Notes 28, 153-161.

Cameron, R. L. 1964. Glaciological studies at Wilkes Station, Budd Coast, Antarctica. In Mellor, M., ed. Antarctic snow and ice studies. Washington, DC, American Geophysical Union, 1-36. (Antarctic Research Series 2.)

Dansgaard, W. and S. J. Johnsen. 1969. A flow model and a time scale for the ice core from Camp Century, Greenland. J. Glaciol., 8 (53), 215-223.

Deshler, T., A. Adriani, G. P. Gobbi, D. J. Hofmann, G. di Donfrancesco and B. J. Johnson. 1992. Volcanic aerosol and ozone depletion within the Antarctic polar vortex during the austral spring of 1991. Geophys. Res. Lett., 19 (18), 1819-1822.

Domack, E. W., A. J. T. Jull, J. B. Anderson and T. W. Linick. 1991. Mid-Holocene ice sheet recession from the Wilkes Land continental shelf, East Antarctica. In Thomson, M. R. A., J. A. Crame and J. W. Thomson, eds. Geological evolution of Antartica. Cambridge, etc., Cambridge University Press, 693 - 698.

Goodwin, I. D. 1993. Holocene deglaciation, sea-level change and the emergence of the Windmill Islands, Budd Coast, Antarctica. Quat. Res., 40 (1), $70-80$.

Goodwin, I. D. 1995. On the Antarctic contribution to Holocene sea-level. (Ph.D. thesis, University of Tasmania.

Gow, A. J. and T. Williamson. 1976. Rheological implications of the internal structure and crystal fabrics of the West Antarctic ice sheet as revealed by deep core drilling at Byrd Station. CRREL Rep. 76-35.

Hamley, T. C., V. I. Morgan, R. J. Thwaites and X. Q. Gao. 1986. An icecore drilling site at Law Dome summit, Wilkes Land, Antarctica. A.NARE Res. Notes 37.

Hammer, C. U. 1980. Acidity of polar ice cores in relation to absolute dating, past volcanism, and radio-cchoes. f. Glaciol., 25 (93), $359-372$.

Handler, P. 1989. The effect of volcanic aerosols on global climate. F. Volcanol. Geotherm. Res., 37, 233-249.

Jacka, T. H. and L. Jun. 1994. The steady-state crystal size of deforming ice. Ann. Glaciol., 20, 13-18.

Jouzel, J. and 6 others. 1987. Vostok ice core: a continuous isotope temperature record over the last climatic cycle (160,000 years). Nature, 329 (6138), 403408.

Koerner, R. M. and D. A. Fisher. 1979. Discontinuous flow, ice texture, and dirt content in the basal layers of the Devon Island ice cap. J. Glaciol., 23(89), 209-222.

Langway, C. C., Jr, K. Osada, H. B. Clausen, C. U. Hammer and H. Shoji. 1995. A 10-century comparison of prominent bipolar volcanic events in ice cores. 7. Geophys. Res., 100 (D8), 16,241-16,247.

Li, J. 1996. Interrelation between flow properties and crystal structure of snow and ice. (Ph.D. thesis, University of Melbourne.)

Li, J., Z. C. Xie and M. H. Hong. 1988. [Study of the structure of ice core from $\mathrm{BHQ}$ borehole on Law Dome, Antarctica.] In Xie, Z.C., ed. [A collection of Antarctic scientific explorations: studies on glaciology.] Vol. 5. Beijing, Science Press, 119 -131. [In Chinese with English summary.]

Lorius, C., L. Merlivat, P. Duval, J. Jouzel and M. Pourchet. 1981. Evidence of climatic change in Antarctica over the last 30000 years from the Dome C ice core. International Association of Hydrological Sciences Publication 131 (Symposium at Canberra 1979-Sea Level, Ice and Climatic Change), $217-225$.

Monzicr, M., C. Robin andJ. -P. Eissen. 1994. Kuwae ( 1425) the forgotten caldera. J. Volcanol. Geotherm. Res., 39, 207-218.

Moore, J. C., H. Narita and N. Maeno. 1991. A continuous 770-year record of volcanic activity from East Antarctica. 7. Geophys. Res., 96 (D9), 17,353$17,359$.

Morgan, V. I. and A. P. McCray. 1985. Enhanced shear zones in ice flowimplications for ice cap modelling and core dating. A.NARE Res. Notes, $28,4-9$.

Morgan, V. I., E. R. Davis and E. Wehrle. 1984. A Rigsby stage with remote computer compatible output. Cold Reg. Sci. Technol., 10 (1), 89-92.

Pang, K. D. 1993. Climatic impact of the mid-fifteenth century Kuwae caldera formation, as reconstructed from historical and proxy data. [Abstract.] EOS, 74 (43), Supplement, 106.

Paterson, W. S. B. 1991. Why ice-age ice is sometimes "soft". Cold Reg. Sci. Technol., 20 (1), $75-98$.

Paterson, W. S. B. 1994. The physics of glaciers. Third edition. Oxford, etc., Elsevier.

Pfitzner, M. L. 1980. The Wilkes Ice Cap project 1966. ANARE Sci. Rep., Ser. A(4). Glaciology 127.

Sigg, A. and A. Neftel. 1988. Seasonal variations in hydrogen peroxide in polar ice cores. Ann. Glaciol., 10, 157-162.

Souchez, R. and 8 others. 1994. Stable isotopes in the basal silty ice preserved in the Greenland ice sheet at Summit: environmental implications. Geophys. Res. Lett., 21 (8), 693696.

Taylor, K. C. and 9 others. 1993. Electrical conductivity measurements from the GISP2 and GRIP Greenland ice cores. Nature, 366 (6455), 549-552.

Tison, J. L., T. Thorsteinsson, R. D. Lorrain and J. Kipfstuhl. 1994. Origin and development of textures and fabrics in basal ice at Summit, central Greenland. Earth Planet. Sci. Lett., 125, 421-437.

Wang Wei Li. 1994. Laboratory studies of flow properties and associated structures in Holocene and Wisconsin ice. (M.Sc. thesis, University of Tasmania.)

Xie, Z. 1985. Ice formation and ice structure on Law Dome, Antarctica. Ann. Glaciol., 6, 150-153.

Xie, Z., J. Li and N. W. Young. 1989. Physical characteristics of the snow and ice cover of Law Dome, East Antarctica. In Chinese Committee on Antartic Research. Proceedings of the International Symposium on Antarctic Research, Hangzhou, China. Beijing, China Ocean Press, 8 - 22.

Yao, T. D., J. R. Petit, J. Jouzel, C. Lorius and P. Duval. 1990. Climatic record from an ice margin area in East Antarctica. Ann. Glaciol., 14, 323327.

Zielinski, G. A. and 8 others. 1994. Record of volcanism since 7000 B.C. from the GISP2 Greenland ice core and implications for the volcano-climate system. Science, 264 (5161), 948-952. 